УДК 82I.I6I.I

ББК $83.3(2 \mathrm{Poc}=\mathrm{Pyc}) 52$
ГОГОЛЬ И ЗАПАДНОЕ

СЛАВЯНОФИЛЬСТВО: К ПОСТАНОВКЕ ПРОБЛЕМЫ

Аннотация: Наследие Гоголя анализируется с неожиданной, «непривычной» стороны. Впервые писатель представлен как один из главных отечественных идеологов славянского единства. Взгляды Гоголя по этому вопросу рассматриваются в контексте разных течений славянофильства. Несмотря на кажущуюся «маргинальность» вопроса, ставшего предметом изучения, открывается, что полемика писателя с представителями западной ветви славянофильства красной нитью проходит сквозь все его творчество. Позиция Гоголя выявляется на историческом фоне различных представлений о единстве славян «московских» и польских славянофилов; в сравнении с «украинофильскими» воззрениями гоголевского земляка О.М. Бодянского; в связи с начинаниями министра народного просвещения С.С. Уварова, предписавшего в I835 г. изучение в университетах истории и литературы славянских народов. В поле зрения исследования - известное «дело о вольнодумстве», коснувшееся Гоголя еще в пору его обучения в Нежинской гимназии в I820-х гг.; общение писателя в I836I837 гг. за границей с польскими эмигрантами, участниками польского восстания I830-I83I гг.; парижские лекции А. Мицкевича в Collège de France I840-I844 гг.; затрагивается история Украино-Славянского Общества I846-I847 гг., последствия публикации в Москве I848 г. сочинения английского посла в России в XVI в. Джайлса Флэтчера «О Государстве Русском», а также истоки польской идеологической доктрины о так называемом «туранстве» русских, отказывающей, без всяких на то оснований, самой крупной ветви в семье славянских народов в славянских корнях. Рассматривается разнообразное отражение славянских интересов и воззрений Гоголя в его художественном творчестве и публицистике, в общении с друзьями и знакомыми, вплоть до последних лет жизни. Приводится обширная библиография по рассматриваемому вопросу.

Ключевые слова: Гоголь, биография, художественное творчество, общественная идеология, славянофильство, интерпретация, герменевтика, духовное наследие.

Информация об авторе: Игорь Алексеевич Виноградов - доктор филологических наук, ведущий научный сотрудник, Институт мировой литературы им. А.М. Горького Российской академии наук, ул. Поварская, д. 25 а, І2Іо69 г. Москва, Россия.

E-mail: info@imli.ru 


\section{GOGOL AND THE WESTERN SLAVOPHILIA IN CRITICAL PERSPECTIVE}

This is an open access article distributed under the Creative Commons Attribution 4.0 International (CC BY 4.0)
(C) 20I7. I.A. Vinogradov

A.M. Gorky Institute of World Literature

of the Russian Academy of Sciences, Moscow, Russia

Received: June 28, 2017

Date of publication: December 25, 2017

Abstract: The essay examines Gogol's heritage from a new and somewhat "unusual" perspective: the writer is seen as one of the main Russian ideologists of the Slavic unity. Gogol's views are therefore placed in the context of different Slavophilic trends. The question that this study addresses is only seemingly marginal; as the research has revealed, the polemics between Gogol and the representatives of the Western branch of Slavophilism is central to the work of the former. The essay analyzes Gogol's views against the background of various ideas about the unity of the Slavs of the "Moscow" and Polish Slavophilic groups, in comparison with "Ukrainophile" views of Gogol's countryman O.M. Bodiansky, and in their relation to the initiatives of the Minister of Public Education S.S. Uvarov who prescribed the study of the history and literature of the Slavic peoples at universities in I835. The essay focuses on the well-know "dissident case" (delo o volnodumstve) that affected Gogol already as a student at Nezhinskaya gymnasium in the I820s. It also covers such subjects as: Gogol's communication with Polish emigrants, participants of the Polish uprising (I830-I83I), when he was abroad in I836-I837; Mickiewicz's Parisian lectures in Collège de France in $1840-1844$; the history of the Ukrainian-Slavic Society in I846-I847; and the consequences of the publication of the book About the Russian State by Giles Fletcher, British ambassador to Russia in the $16^{\text {th }}$ century. It also pays attention to the origins of the Polish ideological doctrine concerning the so-called "turanism" of the Russians. Thus, the article discusses the reflection of various Slavic interests and views in Gogol's fiction and essays, and in his correspondence with friends and acquaintances, up until the last years of his life. An extensive bibliography on the subject is also provided.

Keywords: Gogol, biography, literary work, ideology, slavophilia, interpretation, hermeneutics, heritage.

Information about the author: Igor' A. Vinogradov, DSc in Philology, Senior Researcher, A.M. Gorky Institute of World Literature of Russian Academy of Sciences, Povarskaya 25 a, I21069 Moscow, Russia.

E-mail: info@imli.ru 
В I844 г. А.И. Герцен после прочтения первых двух курсов парижских лекций А. Мицкевича записал в дневнике: «Мицкевич - славянофил, вроде Хомякова и $\mathrm{C}^{\text {nie }}<$ компания>, со всею той разницей, которую ему дает то, что он поляк, а не москаль...» [24, с. 333]. Разница во взглядах Мицкевича и московских славянофилов была, действительно, принципиальной и объяснялась основным, вероисповедным отличием; она заключалась в прямо противоположной оценке наполеоновских кампаний и фигуры Наполеона I в целом. Друг и коллега Гоголя по Петербургскому университету славянофил Ф.В. Чижов в том же І844 г. сообщал Н.М. Языкову из Парижа: «Мицкевич горит огнем славянолюбия <...> Это славянин душою и телом, но все-таки славянин западный. <..> Когда я приехал, лекции его уже кончались, я присутствовал только на одной последней, где он и показался чрезвычайно странным и которую он кончил раздачею Наполеона в апотеозе. $<. . .>$ Это не слово славянина, это влияние западной крови...» [42, с. I25] $]^{\mathrm{I}}$.

«Пророчества» Мицкевича о «мессии»-Наполеоне вскоре достигли и Гоголя. А.О. Смирнова 29 марта (н. ст.) г844 г. сообщала ему из Парижа: «Говорят, что Мицкевич почти с ума сошел и не окончил курса; я это уз-

I Согласно документу, с Мицкевичем Чижов «имел не столько дружбы, сколько споров, ибо Мицкевич в своих лекциях о славянским племенах вовсе не упоминал о русских, а Чижов несколько раз ходил к Мицкевичу именно с тем, дабы доказать, что, рассуждая о славянах, несправедливо и невозможно забывать о столь могущественном племени, как русские» (Продолжение журнала действий III Отделения Собственной Его Императорского Величества Канцелярии по делу коллежского секретаря $<$ Н.И.> Гулака и Славянского общества. 24 апреля - I4 июня I847 г. // [33, с. 365]). 
нала от поляков. Товянского отсюда выслали» [25, т. I2, с. 354 $]^{2}$. (Анджей Товянский был главным, среди польских эмигрантов, идеологом «мессианизма» Наполеона и Польши.) 26 февраля (н. ст.) I845 г. проживавший в Париже А.И. Тургенев, в свою очередь, записал в дневнике: «У меня были Гоголь, гр $<$ аф $><$ А. П. $>$ Толстой ${ }^{3}<\ldots>$ и Циркур 4 . Он объяснил нам мессианизм так, что Гог<оль $>$ и Тол<стой $>$ не поехали к Мицкев<ичу $>$ расспрашивать его о нем» [I4, т. 3, с. 79].

Известно, что идея общности славян являлась в XIX в. одной из составляющих польской (и французской) пропаганды среди малороссов (см.: [2, с. 94; 5I, c. I5I-I 55]). Неудивительно, что в России сепаратистские идеи западного славянофильства встречали активное противодействие. Наиболее показательно в этом отношении расследование в г847 г. сепаратистской деятельности Украино-Славянского общества (организаторы называли свой кружок Обществом Святых Кирилла и Мефодия). Изучение славянства к тому времени приобрело в России весьма широкий характер. Начало этому положил сам министр народного просвещения С.С. Уваров. В г835 г. он выступил с инициативой создания в российских университетах славянских кафедр5 . В г847 г., в связи с делом «кирилло-мефодиевцев», Уваров должен был разъяснять официальную точку зрения на славянофильство. В своем циркуляре на имя попечителя Московского округа он указывал, что в деле отечественного образования начало народности важнее идеи славянского единства. По словам Уварова, основой российского славянофильства должно быть «наше государственное начало <...>, собственно Русское начало»

2 I2 апреля (н. ст.) І844 г. Гоголь извещал графиню С.И. Соллогуб: «От Александры Осиповны получил письмо из Парижа. <...> О Париже пишет слегка, так что из слов ее видно только, что Париж в смутах и погрузнул весь в настоящее, не заглядывая ни в прошедшее, ни в будущее» [25, т. І2, с. 362].

3 Граф Александр Петрович Толстой, друг Гоголя, постоянный собеседник писателя по конфессиональным вопросам; впоследствии, в І856-1862 гг., - прокурор Святейшего Синода. 4 Граф Адольф Мария Пьер де Сиркур (Циркур), французский публицист и историк, приятель П.Я. Чаадаева; был женат на Анастасии Семеновне Хлюстиной, хозяйке литературного салона в Париже (в I84I г. перешла в католичество). Гоголь, вернувшись из Парижа во Франкфурт, 5 марта (н. ст.) І845 г. писал графу А.П. Толстому: «Познакомьтесь <...> с графинею Сиркур и дайте мне сведение о ней, точно ли она так умна, как говорят, в каком роде ум и в такой ли степени, как говорит Тургенев» [25, т. І2, с. 43].

5 Новым университетским уставом, разработанным в г835 г. Уваровым, впервые предписывалось изучение в университетах «Истории и Литературы Славянских Наречий» (см.: Июля $26<\mathrm{I} 835>$. Высочайше утвержденный Общий Устав Императорских Российских Университетов // [40, с. 842]). 
(см.: [7, с. 348; 33, с. 3ІІ]). Повторяя Н.М. Карамзина ${ }^{6}$, Уваров замечал, что из всех славян одна только Россия «выдержала удары судеб и приобрела самобытность», что «всё, что имеем мы на Руси, принадлежит нам одним, без участия других Славянских народов, ныне простирающих к нам руки и молящих о покровительстве» [7, с. 349-350].

В циркуляре, адресованном попечителю Киевского округа, Уваров добавлял: «Под личиною Славянства может скрыться мятежный дух польский, готовый уловить умы неопытного юношества» [28, с. 205]. Для такого вывода оснований у Уварова было достаточно. С давних пор естественное стремление славян к единению польские националистические круги использовали в целях отторжения от России Южной Руси. В этом направлении действовала, к примеру, в конце І8го - начале І820-х гг. киевская масонская ложа «Соединенных Славян», главой которой был близкий к декабристам В.Л. Лукашевич (получивший в I82I г. степень тамплиера (храмовника) от члена варшавской ложи Изиды, польского капитана Ф.С. Маевского; см.: [26, с. 279; 44, с. 506, Іог6, ІІз32]). В ту же пропольскую ложу «Соединенных Славян» входили знакомые Лукашевича, два преподавателя нежинской Гимназии высших наук, где учился Гоголь. Это профессора Казимир Шапалинский - воспитанник Виленского университета (закрытого после польского восстания) - и уроженец Шампани Иван (или Жан) Ландражен «бывший простой солдат Наполеонова войска» [I7, с. 94]. Оба они в I830 г. были осуждены по известному нежинскому «делу о вольнодумстве».

Позднее с представителями западного, прежде всего польского, «славянофильства» Гоголь имел случаи сталкиваться еще не раз. Создателю «Тараса Бульбы» (г835) необходимо было не по слухам убедиться, насколько противоречащей интересам России являлась любовь к славянству польского толка. Зимой І836/37 г. в Париже он встречался с самим Мицкевичем, а также с его земляком Богданом Залесским (еще одним представителем польской эмиграции). Спустя год в Риме он свел знакомство с друзьями Мицкевича и Залесского, Иеронимом Кайсевичем и Петром Семененко

6 В заключении первой главы первого тома «Истории государства Российского» Карамзин указывал: «Представив читателю расселение народов славянских <...>, скажем, что они, сильные числом и мужеством, могли бы тогда, соединясь, овладеть Европою; но, слабые от развлечения сил и несогласия, почти везде утратили независимость, и только один из них, искушенный бедствиями, удивляет ныне мир величием (говорим о российских славянах)» [30, c. I8]. 
(тоже бывшими повстанцами). Итогом этого общения была напрасная попытка Гоголя сделать предметом обсуждения с двумя будущими ксендзами своего «Тараса Бульбу» (для этого Гоголь вручил им сборник «Миргород», подробнее см.: [г3, с. 447]), а затем - создание второй, увеличенной вдвое редакции этого произведения, опубликованной в I842 г.

Кайсевич и Семененко, так и не познакомившиеся с гоголевской повестью (прочли они только «Старосветских помещиков»), определенно рассчитывали на «обращение» Гоголя. В своих письмах-отчетах к их патрону Богдану Яньскому они торопились сообщить об «успехах» в этом деле, но, увы, просчитались. Гоголь, уяснив нужное для себя, вскоре с ними навсегда расстался7. Тем не менее неудавшаяся интрига по «обращению» Гоголя надолго запомнилась ее участникам и спустя много лет вылилась в попытку хотя бы очернить писателя.

В конце І850-х гг. Б. Залесский сблизился с Франциском Духинским, создателем пресловутой теории о «туранстве» русских. По этой русофобской теории, великороссы, ничтоже сумняшеся, исключались из числа славянских народов, что служило оправданием распространения Польши на якобы «родственные» только ей украинские и белорусские земли. Разделяя эту теорию, Богдан Залесский в письме к Духинскому сообщал, что будто бы Гоголь во время пребывания в Париже в I836 г. высказывал, вместе с Мицкевичем, «отвращение» К «москалям» ${ }^{8}$ и «со всею своею малорусской запальчивостью» «подтверждал» «финское их происхождение». Залесский заявлял, что Гоголь, пользуясь «сборниками народных песен на разных славянских наречиях», будто бы написал тогда статью, в которой указывал на «отличия в духе, обычаях и в нравственных взглядах у великоруссов и у других славянских народов». «Для характеристики каждого человеческого

7 По наблюдениям исследователей, на сближение с А. Мицкевичем, Б. Залесским, И. Кайсевичем и П. Семененко Гоголь шел главным образом для изучения новых знакомых. Польские эмигранты интересовали Гоголя отчасти потому, что проповедуемые ими идеи польского мессианизма, возрождения «рыцарской» Польши, внешним образом напоминали собственные устремления Гоголя к духовному преображению России, его веру в то, что всякий русский человек способен «вдруг» «поступить в рыцарство» [25, т. І2, с. 393]. Эти устремления и определили, с одной стороны, пафос «Мертвых душ» (в его критическом и утверждающем началах), с другой - обусловили создание «Тараса Бульбы» - как произведения о запорожских «рыцарях» (см.: [37, с. 56-57; 27, с. 224, 231, 220]).

$8 \ll$ «верение Залеского, будто Гоголь питал отвращение к великоруссам, мы безусловно отвергаем» (Лященко А.И. Украйнофильство Гоголя. (Свидетельство Богдана Залесского) // $[\mathrm{I} 4$, T. 2, c. 20]). 
чувства, - утверждал Залесский, - он <Гоголь> подобрал особую песню: с одной стороны, нашу славянскую - сладостную, нежную, и рядом великорусскую - угрюмую, дикую, нередко каннибальскую, словом, - чисто финскую. Уважаемый земляк, ты легко можешь себе представить, как эта статья искренно обрадовала Мицкевича и меня. Много лет спустя, в Риме я думал раздобыть у Гоголя эту параллель, но тогда Гоголь уже превратился в защитника Царя и Православия, и мне пришлось отказаться от этой попытки. Какова же, однако, судьба этой статьи? Неужели в посмертном собрании сочинений Гоголя нет ничего подобного? Она послужила бы прекрасным подтверждением твоих выводов» [І4, т. 2, с. I9-20].

Тщетная попытка привлечь для подтверждения «туранской» теории якобы высказанные Гоголем в I836 г. отрицательные суждения о великороссах весьма показательна для польской партии. Лучшим ответом на эти оговоры могли бы служить слова самого Гоголя - в репликах его героев. Приписывать писателю «отвращение» к целому народу - все равно подозревать в нем такие же чувства, какое испытывает к своему собрату герой «Страшной мести»: «Сделай же, Боже, так, чтобы все потомство его не имело на земле счастья!..» [25, т. I-2, с. 245]. Слова эти, в свою очередь, вполне «созвучны» посулам слесарши Пошлепкиной в «Ревизоре»: «Чтоб всей родне твоей не довелось видеть света Божьего!» [25, т. 3-4, с. 278].

Не только безупречный нравственный облик Гоголя, но и сами факты творческой биографии писателя полностью опровергают мнимое «свидетельство» Залесского. Известно, что Гоголь, поступив, благодаря Уварову, на кафедру истории Петербургского университета, в конце I835 г. собирался написать исследование «о духе и характере народной поэзии славянских народов: сербов, словенов, черногорцев, галичан, малороссиян, великороссиян и прочих» [I4, т. І, с. 798]. В этом начинании Гоголь, несомненно, следовал инициативе Уварова по созданию в русских университетах славянских кафедр. Своего намерения Гоголь, однако, не выполнил. В его бумагах сохранились сборники народных песен лишь на русском и украинском языках (см.: [25, т. I7, с. 7-432]). «За Гоголя» такую работу вскоре осуществил его земляк Осип Бодянский, написав магистерское сочинение «О народной поэзии Славянских племен» [10, c. I-I54]. Этим сочинением Бодянский также готовил себя для занятия славянской кафедры в Московском университете (своей карьерой слависта Бодянский был прямо обязан «славянским» 
инициативам Уварова). В почти буквальном соответствии с невоплощенным гоголевским замыслом Бодянский в своем труде рассматривал фольклорные произведения чехов, моравцев, словаков (словенцев), поляков, сербов, великороссиян и малороссиян (включая русинов). Хотя эта небольшая работа Бодянского носила еще весьма поверхностный характер, она тем не менее явилась первым в России исследованием фольклора славянских народов [3, с. I54], - и, вероятно, именно это сочинение Бодянского Залесский приписал много лет спустя ошибочно Гоголю.

Если признавать за словами Залесского хоть какую-то фактическую основу, то, скорее всего, Гоголь зачитывал польскому «украинофилу» фрагменты своих статей «О малороссийских песнях» и «Взгляд на составление Малороссии» (из сборника «Арабески»).

В статье «О малороссийских песнях» Гоголь приводит слова М.А. Максимовича9 о том, что «русская заунывная музыка выражает <...> забвение жизни; она стремится уйти от нее и заглушить вседневные нужды и заботы; но в малороссийских песнях она слилась с жизнью... [25, т. 7 , c. I75]. (На это общее мнение Гоголя и Максимовича ссылался Бодянский в своем труде I837 г. о славянском фольклоре - не называя их имен; см.: [Iо, c. II4].) Однако из этих слов сделать вывод о том, что Гоголю великорусская песня представлялась «угрюмой, дикой, нередко каннибальской», можно лишь при очень предвзятом подходе. В этом вопросе Гоголь оказывался много добрее своих польских знакомых. В I834 г. - еще до встречи с Залесским - Гоголь в еще одной из статей «Арабесок» замечал, что постичь стихи Пушкина может только тот, «чья душа способна понять неблестящие с виду русские песни» $[25$, т. 7 , с. 277]. А спустя около трех лет после встречи с Залесским, в письме к М.П. Погодину, указывал, что в русских песнях «есть <...> особенные, оригинально-замечательные черты <...> Будучи употреблены, как источник, как золотые искры рудниковых глыб, обращенные в цветущую песнь <...> поэзии нынешней <..>, они поразят и зашевелят сильно» [25, т. II, с. 228].

9 Имеются в виду строки «Предисловия» к «Малороссийским песням, изданным М. Максимовичем» (М., І827): «Русские песни отличаются глубокою унылостью, отчаянным забвением, каким-то раздольем и плавною протяженностию» [34, с. I3-I4]. В одном из «Четырех писем к разным лицам по поводу “Мертвых душ”» (І846) Гоголь писал: «Я до сих пор не могу выносить тех заунывных, раздирающих звуков нашей песни, которая стремится по всем беспредельным русским пространствам» [25, т. 6, с. 78]. 
В І8Іг г. Карамзин в своей записке «О древней и новой России...» замечал, что после татаро-монгольского нашествия северорусские города - Владимир, Суздаль, Тверь - хотя и назывались «Улусами Ханскими», «хранили, по крайней мере, свои нравы», - в то время как жители южнорусских городов - попавших под власть Литвы, - Киева, Чернигова и др., «заимствовали и самые обычаи чуждые» [3I, с. 98]. Карамзинская записка могла стать известной Гоголю около февраля I836 г. [І9, с. 487]. Однако сходные мнения о своих земляках Гоголь, вероятно, слышал и ранее. Поскольку подобные отзывы вполне могли показаться ему обидными, то, вероятно, в статье «Взгляд на составление Малороссии» он решил на них возразить. В своей статье он назвал Южную Русь «настоящей отчизной славян, землей <...> чистых славянских племен, которые в Великой России начинали уже смешиваться с народами финскими» [25, т. 7, с. I62]. Возможно, эти полемические строки и имел в виду Богдан Залесский, когда пытался подверстать взгляды Гоголя под «туранскую» теорию. Но для Гоголя вопрос о единстве Русской земли был куда важнее самолюбивой полемики о местном достоинстве. Такая полемика способна была, по убеждению Гоголя, лишь породить бессмысленные, бесплодные распри. В І846 г. он писал: «Уже ссоры и брани начались не за какие-нибудь существенные права <...>: уже враждуют <...> из несходства мнений...» [25, т. 6, с. 200]. Уже по одному этому Гоголь склонялся к более объективной точке зрения. О преодолении братских раздоров он размышлял тогда не только в «Страшной мести» (I832), но и в самой статье «Взгляд на составление Малороссии». Здесь Гоголь, назвав Южную Русь «настоящей отчизной славян», говорит в то же время о множестве враждующих между собой «мелких государств» - «единоверных, одноплеменных, одноязычных», - раздиравших Русскую землю в XIII в. [25, т. 7, с. І6о]. Категорическое неприятие Гоголем удельных ссор нашло тогда же прямое отражение и в повестях его «Миргорода» «Тарасе Бульбе», «Повести о том, как поссорился Иван Иванович с Иваном Никифоровичем» (см.: [16, с. 199-219; І8, с. I9-7I]. Судя по всему, это же неприятие частного и государственного разлада стало впоследствии одним из главных побудительных мотивов создания «Мертвых душ» [20].

В I844 г. Смирнова, пытаясь затронуть «украинство» Гоголя, писала ему: «Спуститесь в глубину души вашей и спросите, точно ли вы русский, или хохлик? Вот о чем у нас шла речь с очень умным человеком» [25, т. І2, с. 467] 
(речь в письме Смирновой идет о Ф.И. Тютчеве). Спустя полторы недели Смирнова добавляла: «Слушайте мои упреки. У Ростопчиной при Вяземском, Самарине и $<$ Ф.И.> Толстом разговорились о духе, в котором написаны ваши “Мертвые души” <...><Ф.И.> Толстой и после него Тютчев, весьма умный человек, <...> заметили, что москвич уже никак бы не сказал “два русских мужика”. Оба говорили, что ваша вся душа хохлацкая вылилась в “Тарасе Бульбе”, где с такой любовью вы выставили Тараса, Андрия и Остапа. <...> Но ведь и я родилась в Малороссии, воспиталась на галушках и варениках, и как мне ни мила Россия, а все же я не могу забыть ни степей, ни тех звездных ночей, ни крика перепелов, ни журавлей <аистов> на крышах, ни песен малороссийских бурлаков. Все там лучше, чем на севере, и все чрез Малороссию пройдем мы в Константинополь ${ }^{\text {го }}$, чтобы сдружиться и слиться с западными собратьями славянами. А как и когда забудется, что некогда Украина была свободна, Бог весть! Итак, никто более меня не понимает вашего - может быть, вами самими неузнанное чувство и таящееся от вас самих. Я, впрочем, заметила им, что хохлы вас тоже вовсе не любят и вас в том же упрекают, как и русские. Плетнев это мне еще подтвердил» [25, т. І2, с. 502-503].

На запрос Смирновой по поводу якобы «неузнанного» самим Гоголем, «таящегося» в нем «чувства» национального пристрастия писатель, как известно, отвечал: «Я <...> соединил в себе две природы: хохлика и русского. <...> Обе природы <...> щедро одарены Богом, и <..> каждая из них <...> заключает в себе то, чего нет в другой - явный знак, что они должны пополнить одна другую. Для этого самые истории их прошедшего быта даны им непохожие одна на другую, дабы порознь воспитались различные силы их характеров, чтобы потом, слившись воедино, составить собою нечто совершеннейшее в человечестве» [25, т. І2, с. 477, 559].

Iо Очевидно, Смирнова передает здесь суждения Тютчева. Идеей освобождения Константинополя поэт проникся еще в отроческие годы в разговорах с своим отцом, Иваном Николаевичем Тютчевым (I776-I846), воспитанником Греческого корпуса, основанного Екатериной II для осуществления этого проекта. Предполагался раздел Турции и создание на юго-востоке Европы Греческой империи под эгидой представителя дома Романовых, со столицей в Константинополе. В марте І82I г. Тютчев беседовал об этом с М.П. Погодиным (см.: [49, с. І2]). В начале октября І829 г. поэт перевел стихотворение баварского короля Людвига I, посланное в I829 г., вместе с автографом, русским посланником при Баварском дворе И.А. Потемкиным вице-канцлеру К.В. Нессельроде. Стихотворение было написано по поводу заключения Андрианопольского договора между Россией и Турцией (2 сентября I829 г.), предоставившего Греции автономию по отношению к Турции. Оно заканчивалось строками: «Стамбул исходит - Константинополь воскресает вновь...» [50, с. 82]. 
Очевидно, Гоголю был вполне чужд взгляд, что будто бы в воссоединении с Россией - или, выражаясь словами Гоголя, в плодотворном «слиянии воедино» с ней - Украина что-то потеряла. В І835 г. в своей лекции «Обозрение Всеобщей Истории» Гоголь замечал: «Царь Алексей Михайлович возвратил от Польши похищенные ею Малороссийские провинции» [25, т. 8 , c. 96]. В записной книжке I846-I850 гг. он также отметил: «Обнять обе половины русского народа, северную и южную, сокровище их духа и характера» [25, т. 9, с. 7II]. Добавим, что подобный взгляд был во многом созвучен размышлениям А.С. Хомякова в статье «О старом и новом» (I839). Согласно его точке зрения, вследствие вызванного нашествием кочевых орд Азии оттока русского населения в глубь страны «Север и Юг смешались, проникнули друг в друга, и началась в пустопорожних землях, в диких полях Москвы, новая жизнь, но уже не племенная и не окружная, но общерусская» [54, с. 52].

Близок к «туранской» теории оказался не Гоголь, радевший о единстве Русской земли (подробнее см.: [II, с. II7-I55; I2, с. 5-24; 25, т. 5, с. 65I]), а его земляк и давний приятель Бодянский в своем крайнем увлечении «украинофильством». В этом отношении, несмотря на некоторое сходство взглядов Бодянского и Гоголя по славянскому вопросу, Бодянский как историк являет собой пример едва ли не противоположный Гоголю.

Сходство интересов Гоголя и Бодянского очевидно. Оба они начинали собиранием и изучением украинского фольклора; оба разделяли представление о русском языке как общем достоянии славянской культуры. Создателю «Тарасу Бульбы» были близки представления Бодянского об историзме украинских народных песен; его взгляд на украинскую историю как на «огромную эпопею» [9, с. 482] (в том и другом вопросе Бодянский прямо опирался на Гоголя [Іо, с. I4, I8, I37]).

Общим интересом отмечено уже самое начало их знакомства, состоявшегося осенью I832 г. на московской квартире Максимовича. Спустя некоторое время в письме к Максимовичу Гоголь, передавая привет Бодянскому, замечал: «...Желаю ему успехов в трудах, так интересных для нас» [25, т. Іо, с. 20I]. Речь в данном случае шла, несомненно, о собирании песен. (Позднее, в I837 г., Бодянский сообщал: «Что касается до многочисленности песень Украинских, то скажем, что в нашем собрании их <...>, начатом за 7 лет пред этим <...>, теперь имеется уже слишком за восемь тысяи, 800о, песень» [10, с. I36].) 
В I835 г. в московском ученом журнале была напечатана статья Бодянского «Рассмотрение различных мнений о древнем языке Северных и Южных Руссов». «Все нынешние Славянские племена, - писал Бодянский, - суть ветви одного древа, и говорили некогда также одним языком <...> Сей язык можно назвать <...> древним Русским языком...» [9, c. 472-473]. Почти в эти же годы Гоголь в своем наброске к незавершенному очерку о славянах (г832-г834) тоже замечал: «Честь сохранения славянского языка принадлежит исключительно русским» [25, т. 8, с. 34]. (Оценка русского языка как «общеславянского» была свойственна, кроме Бодянского, целому ряду современников Гоголя. Такие взгляды, к примеру, были присущи одному из школьных наставников Гоголя, уроженцу Карпатской Руси, ученому с мировым именем И.С. Орлаю [38, с. 323-324]. Сходные взгляды высказывал, со ссылкой на польских ученых, В.Н. Татищев [46, с. 492]; эти же представления разделял Д.Н. Бантыш-Каменский [4, с. г37], славянские писатели и общественные деятели В. Водник [23, с. I50-I5I], К. Кузмани [52, с. 43], В. Ганка [4I, с. 939-940], Л. Штур [57, с. І89]; друзья Гоголя славянофилы М.П. Погодин [39, с. І83-I84], Ф.В. Чижов [55, с. 403-404] и др.; см.: [43, с. 79-Іо8; 29, с. І-8о; 21, с. 8-9, 50-77; 22, с. Іо9-ІІо].)

По поводу украинского фольклора Бодянский - полтавский уроженец - замечал, что «из тщательно собранных исторических песен Сербов и Малороссиян» можно составить «Славянскую Илиаду», а из песен «семейственных» - «Славянскую Одиссею» [го, с. Іо4]. «Из нынешних Европейских народов Славяне всех богаче песнями, своей народной Поэзией, суть самый песенный, поэтический народ», - писал Бодянский [Iо, с. I53]. (В высокой оценке славянской народной поэзии Бодянский и Гоголь, в свою очередь, были не одиноки. Аналогичную исключительную оценку народным песням давали в те годы П.В. Киреевский [32, с. 48], А.С. Хомяков [53, с. 455], граф А.К. Толстой [47, с. 603; 48, с. 70] и др.).

В I837-г838 гг. Бодянский под руководством Погодина перевел на русский язык первый в науке фундаментальный труд о древних славянах чешского слависта П.Й. Шафарика «Славянские древности» (г837) (см.: [58; 56]). Получив этот перевод от самого Шафарика, Гоголь весной г839 г. писал Погодину: «Дивлюсь ясности взгляда и глубокой дельности. Кое-где я встречал мои собственные мысли, которые хранил в себе и хвастался втайне, как открытиями...» [25, т. II, с. 227]. 
Позднее, зимой г848/49 г. Гоголь занимался с Бодянским сербо-лужицким языком, чтобы понимать народные песни, собранные Вуком Караджичем. Годом позже Гоголь с Бодянским и Максимовичем часто посещали Аксаковых, где вместе слушали украинские песни. Примечательно сочувствие Гоголя к судьбе Бодянского, удаленного в I848 г. из Московского университета, и одобрение, высказанное писателем в связи с восстановлением Бодянского в университетской должности в I849 г.

Исследователи подчеркивали одинаково важные заслуги Гоголя и Бодянского «в формировании славянофильской идеологии в России» [3, c. I50]. Бодянский читал в Московском университете курс лекций по «истории и литературе славянских наречий» с I 842 по ноябрь I 848 и с конца I849 по I868. «Можно предположить, - замечает современный исследователь, - что посещение лекций Бодянского способствовало тому, что молодое поколение славянофилов, период высшей общественной и политической активности которых пришелся на I850-I870-е гг., получило солидный багаж научных знаний по славистике. <...> Плодотворные контакты между русскими славянофилами и русской общественностью в целом, с одной стороны, и славянскими “будителями” - с другой, возникли во многом благодаря личным связям и знакомствам Бодянского. В почетные члены Общества истории и древностей российских по настоянию Бодянского были избраны: Д. Зубрицкий (автор “Истории о Червонной (Галицкой) Руси”), а также ученые, литераторы и деятели национального просвещения ряда славянских стран - чехи В. Ганка, Ф. Палацкий и Й. Юнгман, словак Я. Коллар. Несколько позднее почетными членами общества стали профессор славянских наречий, истории и литературы при Братиславском университете Ф. Челаковский и известный польский историк В. Мацеёвский. В “Чтениях” Бодянский впервые опубликовал свой перевод важнейших работ П.Й. Шафарика...» [3, с. I57-158].

При всем этом, однако, исследователь указывает, что «в силу специфики поля своей деятельности, Гоголь охватил своей литературной популяризацией “славянской идеи” гораздо более широкую общественную аудиторию, нежели та, на которую мог рассчитывать в близких к науке кругах О.М. Бодянский» [3, с. I6I]. Соглашаясь с этим выводом, можно тем не менее предположить, что ограниченность «общественной аудитории» Бодянского объяснялась не только спецификой его научной работы. Причиной тому - в числе прочего - были, по-видимому, неумеренные 
украинофильские пристрастия ученого. С самого начала научной деятельности Бодянского эти пристрастия существенно - часто не в лучшую сторону - влияли на содержание его работ.

Уже в самой первой публикации Бодянского - кандидатском сочинении «О мнениях касательно происхождения Руси», защищенном в I834 г. в Московском университете, обнаруживается стремление юного «украинофила» отказать русским и украинцам в их общем происхождении. Будучи учеником М.Т. Каченовского, родоначальника «скептической школы» в русской историографии (известной своим гиперкритицизом), Бодянский не без юношеской самонадеянности заявлял, что «летопись нашего Нестора $<. .>$ не имеет совершенно канонической важности и принадлежит к категории грубых компиляций новейшего времени»: «<Это> летопись, в которую Новгородец внес составленное им по политическим целям производство Руси от двух совсем различных и никогда не имевших ничего между собою общего народов, т. е. Варгов, или Варагов, Немецких Славян при Балтийском море, и Руссов, народа, обитавшего издревле на берегах Черного моря. <...> Те и другие были Славяне, но происшедшие совсем от различных племен» [8, № 38, с. I31, № 39, c. 192].

От подобных размышлений Бодянского (негативно оцененных не только Погодиным, но и земляком и приятелем Бодянского Максимовичем, см.: [35, с. 40-45, 9I-92; 36, с. 36I-362]) оставался лишь шаг до «туранской» теории Духинского. Отличие заключалось лишь в том, что не северных, но, напротив, южных «Руссов», т. е. украинцев, Бодянский называл хоть не «туранским», но «турецким племенем» (тогда как неких исконных славянских «Черноморских Руссов» считал бесследно растворившимися среди других народов) [8, № 39, с. I99]. Впрочем, и теория о «туранстве» русских (великорусов) как бы напрашивалась сама собой из определения Бодянским варягов как племени неких «прибалтийских Германских Славян <...>, основавших Новгородскую республику» [8, № 39, с. 199].

(В отличие от Бодянского, Гоголь, вследза Карамзиным и Погодиным, вполне разделял норманскую теорию, с основательным доверием относясь к «Несторовой Летописи».)

Новым изложением пристрастных выводов и суждений, порожденных украинофильством молодого Бодянского, стало в г837 г. его уже упомянутое магистерское сочинение «О народной поэзии Славянских племен». 
В новом труде Бодянский, ссылаясь на мнение Максимовича и Гоголя о «заунывности» русских песен и о «противоположности» им народной поэзии малороссиян, вновь настаивал на том, что «из всех Славянских Племен Северные и Южные Руссы - самые несходственные между собою, несмотря на одинакость их общего названия» [Іо, с. І22]. Для подтверждения этих взглядов Бодянский привлекал свою нелепую гипотезу I834 г. о разных корнях русского и украинского народов, вновь выражал сомнение в достоверности летописи преподобного Нестора. С очевидной неприязнью писал магистр Бодянский о присущих великороссам «преданности, доверии, послушании» своим Государям; негативно оценивал Переяславскую раду г654 г. - будто бы насильственно заставившую «сынов Украйны <...> войти в систему Белого Царя». Непонятно на чем основываясь, Бодянский утверждал, что жизнь казаков, их «железная Славянская мощь» достигли тогда «высшей степени разгара» - и были «прерваны судьбой на пути величайшего своего расширения»: «Чувствуя свое достоинство и полное право на лучший жребий, <...> козаки покорились своей судьбе. <...> Но <...> что, спрашиваем, такая жизнь такого народа должна была произвести в нем самом? <...> Естественно из груди их должны были вырваться горькие жалобы...» [Іо, с. I3I-I33]. Сходные размышления Гоголь воплотил в I834 г. в своей незавершенной «Истории Малороссии» в воображаемом внутреннем монологе самого изменника Мазепы - «преступного гетьмана», как его определял Гоголь [25, т. 7, с. 158]. (Об измене Мазепы, а также об участи С.Ф. Палея, В.Л. Кочубея и И.И. Искры, которые безуспешно пытались раскрыть Петру I изменнические планы Мазепы, повествуют несколько песен, помещенных Гоголем в его сборник украинских песен и дум (см.: [25, т. I7, c. 395-398]). Комментируя одну из этих песен, И.И. Срезневский писал о Мазепе: «Проклятие, наложенное на его имя, слишком сильно впечатлелось в умах украинцев, - и до сих пор это проклятие преследует имя Мазепы, которое сделалось самым поносным ругательным именем» [45, с. I58].)

Стремясь во что бы то ни стало доказать исключительность «козацкой» нации, Бодянский утверждал, что славянское песенное творчество является вершиной мирового фольклора (в этом, как отмечалось, он еще мог найти себе единомышленников). Но такое утверждение служило Бодянскому лишь проходной ступенью к куда более решительному заявлению о том, что пред всеми народами венцом народного творчества является 
украинский фольклор, что украинские песни-думы «стоят выше песен всех прочих Славянских племен» [Іо, с. I35]. В противовес этому безудержному восхвалению «своего», пожалуй, уместно привести совершенно несхожее (хотя тоже не бесспорное) мнение об украинских песнях-думах другого ученого - известного историка Малороссии Д.Н. Бантыша-Каменского: «Запорожец играл на бандуре, припевая песни, но песни сии уподоблялись жестокому его нраву. Вместо любви и семейственного счастия он воспевал знаменитые убийства и разбои, предками его или им самим учиненные» ${ }^{\text {I. }}$.

В I848 г. Бодянский оказался замешан в неприглядную историю с публикацией сочинения Джайлса Флэтчера «О Государстве Русском». Это сочинение английского посла в России в XVI в. содержало резко критические отзывы о Русской Церкви и русском царе. За эту публикацию Бодянский был наказан: временно, на год, удален из Московского университета. Как и в судьбе московских славянофилов, в этом наказании Бодянского, несомненно, сказалось завершившееся незадолго перед тем разоблачение деятельности Украино-Славянского общества.

Дело получило тогда настолько широкую огласку, что коснулось не только Бодянского. Дошло до того, что в 1847 г. было решено поощрить А.А. Краевского, бывшего сотрудника Уварова в «Журнале Министерства Народного Просвещения», «К продолжению помещения в его журнале статей в опровержение славянофильских бредней» ${ }^{12}$. К тому времени Краевский уже превратился в издателя либерально-западнических «Отечественных Записок»; именно в этом журнале предполагалось печатать статьи, «опровергающие» славянофильство. Тень в то время пала даже на самого Уварова. По словам чиновника III Отделения Н.А. Кашинцова в донесении Л.В. Дубельту от 27 мая I847 г., «этого министра очень порицают за волю, которую он дал профессорам таскаться по чужим краям, особенно за покровительство к Погодину» [33, с. 302].

Все эти крайности становятся более понятными, если иметь в виду, что оправдание политического сепаратизма идеей единства славян Император Николай I называл смешением «преступного с святым» [I, с. 502].

II «История Малой России...» (г822); глава «О Запорожцах и их Сече»: [4, с. Iо-II]; переиздано в г83о г.: [5, с. 6I].

I2 Журнал действий III Отделения Собственной Е. И. В. Канцелярии по делу коллежского секретаря Николая Ивановича Гулака и Славянского общества. I847 г. марта I7 - июня I4 // [33, с. 362]. См. также: [33, с. 298, 308]. 
Однако если в отношении Ф.В. Чижова, А.С. Хомякова, Ю.Ф. Самарина и И.С. Аксакова спровоцированные тогда гонения были действительно незаслуженными, то в отношении Бодянского этого, очевидно, сказать нельзя. Выдвинутое против него обвинение было несправедливым лишь по форме, но не по сути. (Непосредственным инициатором публикации сочинения Флэтчера был не сам Бодянский, а его начальник, попечитель Московского округа граф С.Г. Строганов; подробнее см.: [І4, т. 3, с. 228-230].) Именно с Бодянским в I85I г. Гоголь вступил в спор о поэзии Т.Г. Шевченко, также осужденного по делу «кирилло-мефодиевцев». Гоголь говорил тогда Бодянскому, что уроженцам Южной Руси следует стремиться «к поддержке и упрочению одного, владычного языка <...> для русских, чехов, украинцев и сербов» [I4, т. I, c. 303]. При этом Гоголь убеждал Бодянского, как когда-то Смирнову, что «русский и малоросс - это души близнецов, пополняющие одна другую, родные и одинаково сильные»: «Отдавать предпочтение одной, в ущерб другой, невозможно». По свидетельству Г.П. Данилевского, присутствовавшего при этом разговоре, Бодянский, споря с Гоголем, «далеко не соглашался» с ним, горячился и возражал [І4, т. I, с. 303]. Судя по содержанию исторических работ Бодянского, полемика с ним Гоголя, как и возражения на сочинения Бодянского Михаила Максимовича, была не случайной. Учитывая их долгое «земляческое» общение, можно предположить, что такие же принципиальные столкновения бывали между ними и ранее. Напомним ироническое замечание Гоголя в «Мертвых душах» о некоем самонадеянном ученом, выдвигающем гадальные предположения о происхождении Руси и «разговаривающем с древними писателями запросто» $[25$, т. 5 , с. I82]. Возможно, именно по этой причине - по причине гоголевской «непримиримости» к нелепым суждениям Бодянского - тот еще за год до спора о Шевченко называл Гоголя «человеком в высшей степени самолюбивым» [14, т. 3, с. 227].

Гоголю, несмотря на его глубокие славянофильские убеждения [15, c. 20-27], отнюдь не было свойственно безоговорочное одобрение всего славянского. При неизменной любви к России он был далек от идеализации как русской, так и украинской истории. Более того, какие-то явления вызывали его резкую, принципиальную критику. В наибольшей мере, как уже отмечалось, это относится к многочисленным княжеским распрям, «ссорам», часто расторгавшим русское и славянское единство. С этим напрямую связа- 
но пророческое восклицание Тараса Бульбы: «Подымется из Русской земли свой царь!..» [25, т. I-2, с. 413]. Ради чаемого славянского единства Гоголь готов был воздать должное даже Мицкевичу, когда тот выступил однажды с парижской кафедры против вражды и ненависти. В статье «О лиризме наших поэтов» «Выбранных мест из переписки с друзьями» Гоголь замечал: «Царственные гимны наших поэтов изумляли самих чужеземцев своим величественным складом и слогом. Еще недавно Мицкевич сказал об этом на лекциях Парижу, и сказал в такое время, когда и сам он был раздражен противу нас, и все в Париже на нас негодовало. <...> Он объявил торжественно, что в одах и гимнах наших поэтов ничего нет рабского или низкого, но, напротив, что-то свободно-величественное <...> Мицкевич прав» [25, т. 6, с. 49].

Сама по себе эта давняя, неизменная направленность гоголевской мысли к духовному и политическому единству славян свидетельствует о том, что писателю были чужды как идеи украинского сепаратизма, так и соответствующие ему начала западного славянофильства. Критическим отзывом об украинских сепаратистах Гоголь и завершил в I85і г. свою полемику с Бодянским: «Они все еще дожевывают европейские, давно выкинутые жваки. <...> Нет, Осип Максимович, не то нам нужно, не то. <...> Доминантой для русских, чехов, украинцев и сербов должна быть единая Святыня - язык Пушкина <...> Всякий пишущий теперь должен думать не о розни; он должен прежде всего поставить себя перед лицо Того, Кто дал нам вечное человеческое слово...» [І4, т. І, с. 303].

\section{Список литературы}

I Аксаков И.С. Письма к родным. 1844-1849 / изд-е подг. И.Ф. Пирожкова. М.: Наука, І988. 704 с.

2 Аристов Н.Я. Иноземное влияние в России, изображенное Гоголем в его сочинениях // Аристов Н.Я. Сочинения Н.В. Гоголя со стороны отечественной науки. СПб.: Изд-е книгопродавца Н.Г. Мартынова, І887. С. 67-І48.

3 Аристова Л.Ю. О.М. Бодянский, Н.В. Гоголь и становление идеи «славянского единства» в России // Славянский альманах 2009. М.: Индрик, 201о. С. I50-165. $<$ Бантыш-Каменский Д.Н.> Д. Б. К. Путешествие в Молдавию, Валахию и Сербию. М.: В Губернской тип. А. Решетникова, г8го. 192 с.

$5<$ Бантыш-Каменский Д.Н.> История Малой России со времен присоединения оной к Российскому Государству при Царе Алексее Михайловиче, с кратким обозрением первобытного состояния сего края. М.: В Тип. С. Селивановского, І822. Ч. 2. 324 с. 
<Бантыш-Каменский Д.Н.> История Малой России. Со времен присоединения сей страны к Российскому Государству до избрания в Гетманы Мазепы. М.: Тип. С. Селивановского, г830. Ч. 2. 223 с.+ 62 с.

$7 \quad$ Б<артенев> П.И. Об Украйно-славянском обществе. (Из бумаг Д.П. Голохвастова) // Русский Архив. г892. № 7. С. 334-359.

8 Бодянский И. О мнениях касательно происхождения Руси // Сын Отечества и Северный Архив. І835. № 37. С. 6I-86; № 38. С. II7-I4I; № 39. С. I75-I99.

9 Бодянский И. Рассмотрение различных мнений о древнем языке Северных и Южных Руссов // Ученые записки Императорского Московского ун-та. І835. Сентябрь. № III. С. 472-49I.

Iо $<$ Бодянский O.M> О народной поэзии Славянских племен. Рассуждение на степень Магистра Философского Факультета первого Отделения, Кандидата Московского университета, Иосифа Бодянского. М.: В Тип. Н. Степанова, І837. 54 с.

II Виноградов И.А. Москва и Рим в творчестве Гоголя // Москва в русской и мировой литературе. М.: ИМЛИ РАН, 2000. С. II7-I55.

I2 Виноградов И.А. Гоголь и славянство (К проблеме языкового единства славян) // Язык классической литературы. М.: ИМЛИ РАН, 2007. Т. І. С. 5-24.

I3 Виноградов И.А. Комментарий // Гоголь Н.В. Тарас Бульба. Автографы, прижизненные издания. Историко-литературный и текстологический комментарий. М.: ИМЛИ РАН, 2009. С. 387-656.

I4 Виноградов И.А. Гоголь в воспоминаниях, дневниках, переписке современников. Полный систематический свод документальных свидетельств: в 3 т.

М.: ИМЛИ РАН, 2OII-20I3. Т. I-3. 904 с. + I03І с. + II68 c.

I5 Виноградов И.А. Гоголь о единстве славян // Гоголь и традиционная славянская культура. Двенадцатые Гоголевские чтения. М.; Новосибирск: Новосибирский изд. дом, 2012. С. 20-27.

I6 Виноградов И.А. Н.В. Гоголь как славянофил: Славянская тема в наследии писателя // Проблемы исторической поэтики. Сборник научных трудов. Петрозаводск: Изд-во Петрозаводского гос. ун-та, 20I4. Вып. І2: Евангельский текст в русской литературе XVIII-XXI веков: цитата, реминисценция, мотив, сюжет, жанр. C. 199-219.

I7 Виноградов И.А. Гоголь в Нежинской гимназии высших наук: Из истории образования в России. Научное издание. М.: ИМЛИ РАН, 20I5. 352 с.

I8 Виноградов И.А. История в наследии Гоголя // Гоголезнавчі студії. Гоголеведческие студии. Ніжин, 2015. Вып. 5 (22). С. І9-7I.

I9 Виноградов И.А. Летопись жизни и творчества Н.В. Гоголя (I809-I852). Научное издание: в 7 т. М.: ИМЛИ РАН, 20I7. Т. 2: 1829-І836. 672 с.

20 Виноградов И.А. Блаженны миротворцы. От повести о двух Иванах к замыслу «Мертвых душ» // Вестник Московского университета. Серия 9: Филология. 2017 (принято в печать). 
Виноградов В.В. Великий русский язык. М.: ОГИЗ, Гос. изд-во худож. лит., І945. I72 c.

Водовозов Н.В. Славянские интересы Гоголя // Уч. зап. Моск. гор. пед. ин-та им. В.П. Потемкина. Кафедра рус. литературы. І96о. Т. Іо7. Вып. Іо. С. ІоI-II5. Воскресенский Г. Валентин Водник. Очерк из истории словенской литературы // Сборник статей по славяноведению, составленный и изданный учениками В.И. Ламанского по случаю 25 -летия его ученой и профессорской деятельности. СПб., І883. С. I49-155.

4 Герцен А.И. Собр. соч.: в 30 т. М.: Изд-во Академии наук СССР, ИМЛИ РАН, 1954. T. $2.516 \mathrm{c}$.

5 Гоголь Н.В. Полн. собр. соч. и писем: в I7 т. (I5 кн.) / сост., подгот. текстов и коммент. И.А. Виноградова, В.А. Воропаева. М.; Киев: Изд-во Московской Патриархии, 2009-2010. Т. І-І7. 664 с. +688 с. +68 о с. +744 с. +8 I6 c. +720 c. +968 c. +392 c. +488 c. +704 c. +592 c. +608 c. +624 c. +816 c. +936 c.

6 Декабристы. Биографический справочник. М.: Наука, І988. 448 с.

7 Десницкий В.A. «Мертвые души» Гоголя как поэма дворянского возрождения // Десницкий В.А. На литературные темы. М.; Л.: Худож. лит., І933. С. 220-23I. Жуковская Т.Н. С.С. Уваров и Кирилло-Мефодиевское общество или кризис «официальной народности» // Отечественная история и историческая мысль в России XIX-XX веков: сборник статей к 75-летию А.Н. Цамутали. СПб.: Изд-во «Нестор-История», 2006. С. 196-207.

Казанский П.Е. Русский язык в Австро-Венгрии. Одесса: Тип. «Техник», I9I2. С. І-8о. Карамзин Н.М. История государства Российского. (Репринтное воспроизведение издания І842-І844 гг.): в І2 т. (в 3 кн.). М.: Книга, І988. Т. І. I56 с.

I Карамзин Н.M. О древней и новой России в её политическом и гражданском отношениях / подг. текста и коммент. А.Ю. Сергеня // Лит. учеба. І988. № 4. C. $97^{-142 .}$

$2<$ <иреевский П.В.> Письма П.В. Киреевского к Н.М. Языкову / ред., вступ. ст. и коммент. М.К. Азадовского. М.; Л.: Изд-во Академии наук СССР, І935. 86 с. 3 Кирило-Мефодіївське товариство: в 3 т. Київ: Наук. думка, І99о. Т. 3.440 с. $4<$ Максимович М.A.> Малороссийские песни, изданные М. Максимовичем. М.: Тип. Августа Семена при Императорской Медико-Хирургической Академии, I827. $234 \mathrm{C}$.

5 Максимович М.А. Откуда идет Русская земля, по сказанию Несторовой повести и по другим писаниям русским <І837> // Максимович М.А. Собр. соч. Киев: Тип. М.П. Фрица, І876. Т. г. С. 5-92.

6 Максимович М.А. История древней русской словесности <І839> // Максимович М.А. Собр. соч. Киев: Тип. М.П. Фрица, І88о. Т. 3. С. 346-48о. 7 Марковский М. История возникновения и создания «Мертвых Душ». Киев: Тип. Р.К. Лубковского, І902. 96 с. 
$38<$ Орлай И.С.> О необходимости обучаться преимущественно отечественному языку и нечто о обучении языкам иностранным // Записки, издаваемые от Департамента Народного Просвещения. I825. Кн. I. С. 320-330.

$39<$ Погодин М.П.> М. П. Об обще-славянском литературном языке // Москвитянин. I85I. № I8. Сентябрь. Кн. 2. С. І8I-I85.

40 Полн. собр. законов Российской Империи. Собрание второе. СПб.: Тип. 2-го Отделения Собств. Е.И.В. Канцелярии, І836. Т. Іо. Отд. І. 918 с.

4I Пыпин А.Н., Спасович В.Д. История славянских литератур / 2-е изд., доп. СПб.: Тип. М.М. Стасюлевича, І88г. Т. 2. ІІ29 с.

42 Розанов И.Н. Н.М. Языков и Ф.В. Чижов. Переписка І843-І845 гг. // Лит. наследство. Т. І9-2г. М.: Жур.-газ. объединение, І935. С. го5-I42.

43 Свенщицкий И.С. Обзор отношений Карпатской Руси с Россией в I-ую пол. XIX в. СПб.: Тип. Императорской Академіи Наук, г906. го9 с.

44 Серков А.И. Русское масонство. I73I-2000. Энциклопедический словарь. М.: Российская политическая энциклопедия (РОССПЭН), 200I. І224 с. $<$ Срезневский И.И.> Запорожская Старина. Харьков: В Университетской тип., І838. Ч. 2. Кн. 3. І64 с.

<Татищев В.Н.> История Российская с самых древнейших времен, неусыпными трудами через тридцать лет собранная и описанная Покойным Тайным Советником и Астраханским Губернатором Васильем Никитичем Татищевым. М.: Императорский Московский Университет, І769. Кн. І. Ч. І-2. 600 с.

$47<$ Толстой А.К., граф>. Из переписки гр<афа> А.К. Толстого. І85I-І875 гг. // Вестник Европы. І897. № 4. С. 592-626.

$48<$ толстой А.К., граф>. Отзыв гр<афа> А.К. Толстого о малорусской народной музыке // Киевская Старина. І897. № 5. Отд. 2. С. 70.

49 Тютчев в дневнике и воспоминаниях М.П. Погодина / вступ. ст, публ. и коммент. Л.Н. Кузиной // Лит. наследство. Т. 97. Кн. 2. М.: Наука, 1989. С. 7-29.

50 Тютчев Ф.И. Россия и Запад: Книга пророчеств. Статьи, стихи / сост., примеч. И.А. Виноградова; илл. Ф.В. Домогацкого. М.: Православный Свято-Тихоновский богословский ин-т, І999. 206 с.

5I Ульянов Н.И. Происхождение украинского сепаратизма. М.: Вагриус, 1996. (Репринтное воспроизведение изд. І966 г.; Нью-Йорк; Мадрид.) 288 с.

52 Францев В.А. Державин у славян. Из истории русско-славянских литературных взаимоотношений в XIX ст. Прага, I924. 80 с.

53 Хомяков А.С. Несколько слов о философическом письме (напечатанном в I5 книжке «Телескопа») // Хомяков А.С. Соч.: в 2 т. М.: Московский философский фонд Изд-во «Медиум», І994. Т. г. С. 449-455.

54 Хомяков А.С. О старом и новом. Статьи и очерки / вступ. ст. и коммент. Е.Ф. Егорова. М.: Современник, І988. 462 с.

55 Ф.В. Чижов к художнику А.А. Иванову <Письма І842-г848> // Русский Архив. I884. Кн. I. C. 39I-422. 
56 <Шафарик П.И.> Славянские древности. Сочинение П.И. Шафарика. Перевод с Чешского И. Бодянского. Издано М. Погодиным. Часть историческая.

М.: В Университетской тип., І837. Т. І. Кн. І-2. 318 с. + 332 с.; І838. Т. г. Кн. 3.302 с.

$57<$ Штур Л.> Славянство и мир будущего. Послание славянам с берегов Дуная Людевита Штура. М.: В Университетской тип., г867. г9г с.

58 Slowanské starožitnosti. Sepsal Pavel Josef Šafárik. Oddjl děgepisný. Pomocj Českého museum. W Praze, I837. 1007 s.

\section{References}

I Aksakov I.S. Pis'ma k rodnym. I844-I849 [Letters to relatives. I844-I849]. Moscow, Nauka Publ., I988. 704 p. (In Russ.)

2 Aristov N.Ia. Inozemnoe vliianie v Rossii, izobrazhennoe Gogolem v ego sochineniiakh [The foreign influence in Russia described by Gogol in his writings]. Aristov N.Ia. Sochineniia N.V. Gogolia so storony otechestvennoi nauki [The works of N. Gogol on the behalf the national science]. St. Petersburg, Izd-e knigoprodavtsa N.G. Martynova Publ., I887, pp. 67-I48. (In Russ.)

3 Aristova L.Iu. O.M. Bodianskii, N.V. Gogol' i stanovlenie idei "slavianskogo edinstva" v Rossii [O.M. Bodyansky, N.V. Gogol, and the development of the idea of "Slavic unity" in Russia]. Slavianskii al'manakh 2009 [Slavic Almanac 2009]. Moscow, Indrik Publ., 20I0, pp. I50-I65. (In Russ.)

4 Bantysh-Kamenskii D.N. Puteshestvie v Moldaviiu, Valakhiiu i Serbiiu [Traveling to Moldavia, Wallachia and Serbia]. Moscow, V Gubernskoi tip. A. Reshetnikova Publ., I8Io. I92 p. (In Russ.)

5 Bantysh-Kamenskii D.N. Istoriia Maloi Rossii so vremen prisoedineniia onoi k Rossiiskomu Gosudarstvu pri Tsare Aleksee Mikhailoviche, skratkim obozreniem pervobytnogo sostoianiia sego kraia [The history of Malorossiya from the time of its annexation to the Russian State under the Tsar Alexei Mikhailovich, with a brief review of the primitive state of this region]. Moscow, Tip. S. Selivanovskogo Publ., I822. Vol. 2. 324 p. (In Russ.)

6 Bantysh-Kamenskii D.N. Istoriia Maloi Rossii. So vremen prisoedineniia sei strany $k$ Rossiiskomu Gosudarstvu do izbraniia v Getmany Mazepy [History of Malorossiya. Since the time of the annexation of this country to the Russian State before the election of Hetman Mazepa]. Moscow, Tip. S. Selivanovskogo Publ., I830. Vol. 2. 223 p. + 62 p. (In Russ.) Bartenev P.I. Ob Ukraino-slavianskom obshchestve. (Iz bumag D.P. Golokhvastova) [On the Ukrainian-Slavic society. (From the papers of D.P. Golokhvastov)]. Russkii Arkhiv, I892, no 7, pp. 334-359. (In Russ.)

8 Bodianskii I. O mneniiakh kasatel'no proiskhozhdeniia Rusi [Opinions on the origins of Rus']. Syn Otechestva i Severnyi Arkhiv, I835, no 37, pp. 6I-86; no 38, pp. II7-I4I; no 39, pp. I75-I99. (In Russ.)

9 Bodianskii I. Rassmotrenie razlichnykh mnenii o drevnem iazyke Severnykh i Iuzhnykh Russov [Analysis of different opinions on the ancient language of the Northern and 


\section{Studia Litterarum /20I7 том 2, № 4}

Southern Russes]. Uchenye zapiski Imperatorskogo Moskovskogo universiteta, I835, september, no 3, pp. 472-49I. (In Russ.)

Io Bodianskii O.M. O narodnoi poezii Slavianskikh plemen [On the folk poetry of the Slavic tribes]. Moscow, Tip. N. Stepanova Publ., I837. I54 p. (In Russ.)

II Vinogradov I.A. Moskva i Rim v tvorchestve Gogolia [Moscow and Rome in Gogol's work]. Moskva v russkoi i mirovoi literature [Moscow in Russian and world literature]. Moscow, IMLI RAN Publ., 2000, pp. II7-I55. (In Russ.) Vinogradov I.A. Gogol' i slavianstvo (K probleme iazykovogo edinstva slavian) [Gogol and the Slavs. On the problem of linguistic unity of the Slavs]. Iazyk klassicheskoi literatury [The language of classical literature]. Moscow, IMLI RAN Publ., 2007, vol. I, pp. 5-24. (In Russ.)

I3 Vinogradov I.A. Kommentarii [Comments]. Gogol' N.V. Taras Bul'ba. Avtografy, prizhiznennye izdaniia. Istoriko-literaturnyi i tekstologicheskii kommentarii [Taras Bulba. Autographs, lifetime editions. Historical and literary and textual commentary]. Moscow, IMLI RAN Publ., 2009, pp. 387-656. (In Russ.)

I4 Vinogradov I.A. Gogol'v vospominaniiakh, dnevnikakh, perepiske sovremennikov. Polnyi sistematicheskii svod dokumental'nykh svidetel'stv: $v 3 t$. [Gogol in the memoirs, diaries, and correspondence of the contemporaries. Full systematic set of documentary evidence]. Moscow, IMLI RAN Publ., 20II-20I3. Vol. I-3. 904 p. + IO3I p. + II68 p. (In Russ.)

I5 Vinogradov I.A. Gogol' o edinstve slavian [Gogol on the unity of the Slavs]. Gogol' $i$ traditsionnaia slavianskaia kul'tura. Dvenadtsatye Gogolevskie chteniia [Gogol and the traditional Slavic culture. Twelfth Gogol readings]. Moscow; Novosibirsk, Novosibirskii izd. dom Publ., 20I2, pp. 20-27. (In Russ.)

I6 Vinogradov I.A. N.V. Gogol' kak slavianofil: Slavianskaia tema v nasledii pisatelia [N.V. Gogol as a Slavophile: Slavic theme in the writer's legacy]. Problemy istoricheskoi poetiki [Problems of Historical Poetics]. Petrozavodsk, PetrSU Publ., 20I4, vol. I2: Evangel'skii tekst v russkoi literature XVIII-XIX vekov: tsitata, reministsentsiia, motiv, siuzhet, zhanr [The Gospel text in Russian literature of the $18^{\text {th }}-20^{\text {th }}$ centuries: Quotation, reminiscence, motif, plot, and genre], pp. I99-2I9. (In Russ.) Vinogradov I.A. Gogol'v Nezhinskoi gimnazii vysshikh nauk: Iz istorii obrazovaniia v Rossii [Gogol in the Nezhinskaya gimnasium: on the history of education in Russia]. Moscow, IMLI RAN Publ., 20I5. 352 p. (In Russ.)

I8 Vinogradov I.A. Istoriia v nasledii Gogolia [History and the legacy of Gogol]. Gogoleznavchi studii. Gogolevedcheskie studii [Gogol's studies]. Nezhin, 2015, issue 5 (22), pp. I9-7I. (In Russ.)

I9 Vinogradov I.A. Letopis' zhizni i tvorchestva N.V. Gogolia (I809-I852): v 7 t. [Chronicle of the life and work of Gogol (I809-I852)]. Moscow, IMLI RAN Publ., 20I7. Vol. 2. I829-I836. 672 p. (In Russ.) 
concept of the Dead Souls]. Vestnik Moskovskogo universiteta, series 9: philology, 2017 (In Russian, unpublished, accepted for printing). (In Russ.)

2I Vinogradov V.V. Velikii russkii iazyk [The Great Russian language]. Moscow, OGIZ, Gos. izd-vo khudozh. lit. Publ., I945. I72 p. (In Russ.)

22 Vodovozov N.V. Slavianskie interesy Gogolia [Slavic interests of Gogol]. Uchenye zapiski Moskovskogo gorodskogo pedagogicheskogo instituta imeni V.P. Potemkina. Kafedra russkoi literatury, I960, vol. I07, issue IO, pp. IOI-II5. (In Russ.)

23 Voskresenskii G. Valentin Vodnik. Ocherk iz istorii slovenskoi literatury [Valentin Vodnik. Essay on the history of Slovenian literature]. Sbornik statei po slavianovedeniiu [Collection of articles on Slavic studies]. St. Petersburg, I883, pp. I49-I55. (In Russ.) Gertsen A.I. Sobranie sochinenii: v 30 t. [Collected works]. Moscow, Izd-vo Akademii nauk SSSR, IMLI RAN Publ., I954. Vol. 2. 516 p. (In Russ.)

25 Gogol' N.V. Poln. sobr. soch. i pisem: $v$ I7 t. ( 15 kn.) [Complete collected works and letters in $\mathrm{I} 7$ vols. ( $\mathrm{I} 5^{\text {th }}$ book) $]$, comp., preparation of texts and comments I.A. Vinogradov, V.A. Voropaev. Moscow; Kiev, Izd-vo Moskovskoi Patriarkhii Publ., 2009-20IO. Vol. I-I7. 664 p. +688 p. +680 p. +744 p. +8 I6 p. +720 p. +968 p. + 392 p. +488 p. +704 p. +592 p. +608 p. +624 p. +816 p. +936 p. (In Russ.)

26 Dekabristy. Biograficheskii spravochnik [Decembrists. Biographical guide]. Moscow, Nauka Publ., I988. 448 p. (In Russ.)

27 Desnitskii V.A. "Mertvye dushi” Gogolia kak poema dvorianskogo vozrozhdeniia [Dead Souls by Gogol as a poem of the nobles' revival]. Desnitskii V.A. Na literaturnye temy [On literary themes]. Moscow; Leningrad, Khudozh. lit. Publ., I933, pp. 220-23I. (In Russ.)

28 Zhukovskaia T.N. S.S. Uvarov i Kirillo-Mefodievskoe obshchestvo ili krizis "ofitsial'noi narodnosti" [S.S. Uvarov and the Cyril and Methodius Society or the crisis of the "official nationality"]. Otechestvennaia istoriia i istoricheskaia mysl' $v$ Rossii XIX$X X$ vekov [Domestic history and historical thought in Russia of the $19^{\text {th }}-20^{\text {th }}$ centuries]. St. Petersburg, Izd-vo “Nestor-Istoriia” Publ., 2006, pp. I96-207. (In Russ.)

29 Kazanskii P.E. Russkii iazykv Avstro-Vengrii [Russian in Austria-Hungarian empire]. Odessa, tip. “Tekhnik” Publ., I9I2, pp. I-80. (In Russ.)

30 Karamzin N.M. Istoriia gosudarstva Rossiiskogo [History of the Russian goverment]. Moscow, Kniga Publ., I988. Vol. I. I56 p. (In Russ.)

3I Karamzin N.M. O drevnei i novoi Rossii v ee politicheskom i grazhdanskom otnosheniiakh [On ancient and new Russia and its political and civil relations], text preparation and comments A.Yu. Sergenya. Literaturnaia ucheba, I988, no 4, pp. 97-I42. (In Russ.)

32 Kireevskii P.V. Pis'ma P.V. Kireevskogo k N.M. Iazykovu [Letters from P.V. Kireevsky to N.M. Yazykov], editorial, introductory article and comments by M.K. Azadovsky. Moscow; Leningrad, Izd-vo Akademii nauk SSSR Publ., I935. 86 p. (In Russ.)

33 Kirilo-Mefodiüv'ke tovaristvo: $v 3 t$. [Cyril-Methodius Society]. Kiev, Nauk. dumka Publ., I990. Vol. 3. 440 p. (In Russ.) 
34 Maksimovich M.A. Malorossiiskie pesni [Malorossyian songs]. Moscow, Tipografiia Avgusta Semena pri Imperatorskoi Mediko Khirurgicheskoi Akademii Publ., I827. 234 p. (In Russ.)

35 Maksimovich M.A. Otkuda idet Russkaia zemlia, po skazaniiu Nestorovoi povesti i po drugim pisaniiam russkim [Where does the Russian land come from, according to the legend of the Nestor's story and other scriptures by the Russians]. Maksimovich M.A. Sobranie sochinenii [Collected works]. Kiev, Tip. M.P. Fritsa Publ., I876, vol. I, pp. 5-92. (In Russ.)

36 Maksimovich M.A. Istoriia drevnei russkoi slovesnosti [History of the ancient Russian literature]. Maksimovich M.A. Sobranie sochinenii [Collected works]. Kiev, Tip. M.P. Fritsa Publ., I88o, vol. 3, pp. 346-48o. (In Russ.) Markovskii M. Istoriia vozniknoveniia i sozdaniia "Mertvykh Dush" [The history of the emergence and creation of the Dead Souls]. Kiev, Tip. R.K. Lubkovskogo Publ., I902. 96 p. (In Russ.)

38 Orlai I.S. O neobkhodimosti obuchat'sia preimushchestvenno otechestvennomu iazyku i nechto o obuchenii iazykam inostrannym [On the need to learn mainly native language and about teaching foreign languages]. Zapiski, izdavaemye ot Departamenta Narodnogo Prosveshcheniia [Notes from the Department of Folk Enlightenment], I825, vol. I, pp. 320-330. (In Russ.)

39 Pogodin M.P. Ob obshche-slavianskom literaturnom iazyke [Concerning general Slavonic literary language]. Moskvitianin, I85I, no I8, september, vol. 2, pp. I8I-I85. (In Russ.) Polnoe sobranie zakonov Rossiiskoi Imperii [Complete collection of laws of the Russian Empire], the second meeting. St. Petersburg, Tip. 2-go Otd-niia Sobstv. E.I.V. Kantseliarii Publ., I836. Vol. Io. Branch I. 918 p. (In Russ.) Pypin A.N., Spasovich V.D. Istoriia slavianskikh literatur [History of Slavic literatures], 2 edition, supplemented. St. Petersburg, Tip. M.M. Stasiulevicha Publ., I88I. Vol. 2. II29 p. (In Russ.) Rozanov I.N. N.M. Iazykov i F.V. Chizhov. Perepiska I843-I845 gg. [N.M. Yazykov and F.V. Chizhov. Correspondence, I843-I845]. Literaturnoe nasledstvo [Literary heritage]. Vol. I9-2I. Moscow, Zhur.-gaz. ob”edinenie Publ., I935, pp. I05-I42. (In Russ.) Sventsitskii I.S. Obzor otnoshenii Karpatskoi Rusi s Rossiei v pervuiu polovinu XIX v. [A review of relations between the Carpathian Rus' and Russia in the first half of the I9 $9^{\text {th }}$ century]. St. Petersburg, Tipografiia Imperatorskoi Akademii Nauk Publ., I906. Io9 p. (In Russ.)

Serkov A.I. Russkoe masonstvo. I73I-20oo. Entsiklopedicheskii slovar' [Russian Freemasonry. I73I-2000. Encyclopedic Dictionary]. Moscow, Rossiiskaia politicheskaia entsiklopediia (ROSSPEN) Publ., 200I. I224 p. (In Russ.) Sreznevskii I.I. Zaporozhskaia Starina [The Old Zaporozhye]. Khar'kov, Universitetskaia tip. Publ., I838. Part 2. Book 3. I64 p. (In Russ.) 
46 Tatishchev V.N. Istoriia Rossiiskaia s samykh drevneishikh vremen [History of Russia since the most ancient times]. Moscow, Imperatorskii Moskovskii Universitet Publ., I769. Book I. Parts I-2. 600 p. (In Russ.)

47 Tolstoi A.K., graf. Iz perepiski grafa A.K. Tolstogo. I85I-I875 gg. [From the correspondence of Count A.K. Tolstoy. I85I-I875]. Vestnik Evropy, I897, no 4, pp. 592-626. (In Russ.)

48 Tolstoi A.K., graf. Otzyv grafa A.K. Tolstogo o malorusskoi narodnoi muzyke [The response of Count A. Tolstoy on Malorossyian folk music]. Kievskaia Starina, I897, no 5, section 2, pp. 70. (In Russ.)

49 Tiutchev v dnevnike i vospominaniiakh M.P. Pogodina [Tyutchev in the diary and memoirs of M.P. Pogodin], introductory article, publication and comments by L.N. Kuzina. Literaturnoe nasledstvo [Literary heritage]. Vol. 97. Book 2. Moscow, Nauka Publ., 1989, pp. 7-29. (In Russ.)

50 Tiutchev F.I. Rossiia i Zapad: Kniga prorochestv. Stat'i, stikhi [Russia and the West: The Book of Prophecy. Articles, poems], comp., notes by I.A. Vinogradov; illustrations F.V. Domogatsky. Moscow, Orthodox St. Tikhon Theological Institute Publ., I999. 206 p. (In Russ.)

5I Ul'ianov N.I. Proiskhozhdenie ukrainskogo separatizma [Origin of Ukrainian separatism]. Moscow, Vagrius Publ., I996. 288 p. (In Russ.)

52 Frantsev V.A. Derzhavin u slavian. Iz istorii russko-slavianskikh literaturnykh vzaimootnoshenii v XIX veke [Derzhavin and the Slavs. On the history of Russian-Slavic literary relationships in the $\mathrm{I}^{\text {th }}$ century]. Prague, 1924.80 p. (In Russ.)

53 Khomiakov A.S. Neskol'ko slov o filosoficheskom pis'me (napechatannom v I 5 knizhke "Teleskopa”) [A few words about the philosophical letter (printed in the $\mathrm{I}^{\mathrm{th}}$ book of the Telescope)]. Khomiakov A.S. Sochineniia: $v 2 t$. [Works]. Moscow, Moskovskii filosofskii fond Izdatel'stvo "Medium” Publ., I994, vol. I, pp. 449-455. (In Russ.)

54 Khomiakov A.S. O starom i novom. Stat'i i ocherki [About the old and the new. Articles and essays], introductory article and comments E.F. Egorov. Moscow, Sovremennik Publ., I988. 462 p. (In Russ.)

55 F.V. Chizhov k khudozhniku A.A. Ivanovu [F.V. Chizhov to the artist A.A. Ivanov]. Russkii Arkhiv, I884, vol. I, pp. 39I-422. (In Russ.)

56 Shafarik P.I. Slavianskie drevnosti. Chast' istoricheskaia [Slavic antiquities. Part of the historical]. Moscow, Universitetskaia tip. Publ., I837. Vol. I. Books I-2. 3I8 p. + 332 p.; I838. Vol. I. Book 3. 302 p. (In Russ.)

57 Shtur L. Slavianstvo i mir budushchego [Slavianstvo and the world of the future]. Moscow, Universitetskaia tip. Publ., I867. I9I p. (In Russ.)

58 Slowanské starožitnosti. Sepsal Pavel Josef Šafárik. Oddjl děgepisný. Pomocj Českého museum [Slowan antiquities. Pavel Josef Safarik. Separated the dialect. Help the Czech Museum]. Prague, I837. 1007 p. (In Czech) 